\title{
DAMPAK RENCANA PENAMBANGAN PASIR BESI TERHADAP KONDISI SOSIAL PETANI LAHAN PANTAI DI DESA BANARAN KECAMATAN GALUR KABUPATEN KULON PROGO
}

\author{
Oleh : \\ Fahmi Isabrin dan Suparmini \\ Jurusan Pendidikan Geografi, Universitas Negeri Yogyakarta
}

\begin{abstract}
$\underline{\text { Abstrak }}$
Penelitian ini bertujuan untuk mengetahui (1) sikap petani lahan pantai terhadap rencana penambangan pasir besi (2) dampak sosial rencana penambangan pasir besi terhadap petani lahan pantai. Penelitian ini merupakan penelitian diskriptif kuantitatif. Metode pengumpulan data menggunakan metode observasi, dokumentasi dan wawancara. Teknik analisis yang digunakan yaitu teknik analisis statistik deskriptif dengan teknik tabel frekuensi berupa angka dan persentase dengan sistem tabulasi. Penelitian ini adalah penelitian sampel, dengan jumlah sampel sebanyak 33 kepala rumah tangga petani lahan pantai. Hasil penelitian menunjukkan (1) Sebanyak $75,76 \%$ petani lahan pantai di Desa Banaran menyetujui adanya rencana penambangan pasir besi di pesisir selatan Kulon Progo karena dapat menciptakan lapangan pekerjaan baru sehingga tingkat kesejahteraan mereka akan meningkat. (2) Berdirinya pilot preject di Desa Banaran menurut $75,76 \%$ responden tidak berpengaruh terhadap kenyamanan tempat tinggal, sedangkan $24,24 \%$ responden mengaku debit air sumur warga berkurang. Rencana penambangan pasir besi tidak berpengaruh terhadap kerukunan antar warga dan frekuensi kegiatan sosial, hanya beberapa warga merasa takut mengikuti kegiatan sosial yang diadakan karena takut dicap sebagai warga yang berseberangan dengan masyarakat sekitar. Pilot project di Desa Banaran menurut 69,70\% responden tidak berpengaruh terhadap aktivitas sehari-hari penduduk, menurut $24,24 \%$ responden berpengaruh karena jalan menuju pilot project rusak, sedangkan sebanyak 6,06\% responden menyatakan berpengaruh karena responden bias berdagang di dekat area pilot project.
\end{abstract}

Kata kunci : dampak sosial, rencana, pasir besi, pilot project

\section{THE IMPACT OF A PLAN FOR MINING IRON SAND ON SOCIAL CONDITIONS OF THE COASTAL FARMERS IN BANARAN VILLAGE, GALUR DISTRICT, KULON PROGO}

\begin{abstract}
This study aims to determine (1) the attitude of the coastal farmers towards iron sand mining plan (2) the social impact of the iron sand mining plan for coastal farmers. This research is a descriptive-quantitative research. The techniques of data collection include observation, documentation and interviews. The data analysis technique used in this research is descriptive statistical analysis techniques by using frequency table in the form of numbers and percentages with tabulation system. This research is categorized as a sample research. The total sample in this research is 33 households' heads of the coastal farmers. The findings show that (1) $75.76 \%$ of the coastal farmers in Banaran village agree with the plan for mining the iron sand in the south coast of Kulon Progo because it can create new jobs so that their welfare increases, (2) $75.76 \%$ respondents states that the pilot project in Banaran village does not affect the comfort of living, while $24.24 \%$ of
\end{abstract}


Dampak Rencana Penambangan Pasir Besi terhadap Kondisi Sosial Petani Lahan Pantai di Desa Banaran Kecamatan Galur Kabupaten Kulon Progo

respondents say that the projects reduce the flow of wells water. The plan for mining Iron sand does not affect the harmonious social relationship among people and the frequency of social activities but some people are afraid to follow the social activities because they are worried of being labeled as residents who are opposed to the surrounding community. Moreover, $69.70 \%$ of respondents state that the pilot project in the village of Banaran does not affect the daily activities of the people, while $24.24 \%$ of the respondents claim that it influences their life because the roads are damaged due to the pilot project. Furthemore, $6.06 \%$ of respondents say that the project influences their life because they can be a trader near the area pilot project.

Keywords: social impacts, plans, iron sand, a pilot project

\section{Pendahuluan}

Dalam sepuluh tahun terakhir, bahan baku untuk pembuatan baja telah menjadi sumber pertumbuhan di beberapa negara yang perekonomiannya kini berkembang, seperti Cina, India dan Australia. Hal ini menyebabkan negara- negara berkembang dengan teknologi yang terbatas menjadi target untuk ekspansi mereka. Negara target ekspansi mereka salah satunya adalah Indonesia, hal ini telah ditunjukkan oleh Keputusan Menteri Perdagangan Nomor 38 Tahun 2008 yang menetapkan bahwa bahan baku seperti pasir besi akan dibebaskan dari bea ekspor. Pemerintah pusat juga memberikan akses yang lebih luas terhadap modal pertambangan melalui dua kebijakan yaitu, Peraturan Pemerintah Nomor 4 Tahun 2009 tentang pertambangan mineral dan batubara serta Peraturan Pemerintah Nomor 25 tahun 2007 tentang penanaman modal. Melalui kedua kebijakan, pemerintah daerah mendapatkan kekuasaan untuk mengeluarkan izin pertambangan, sehingga memungkinkan investor untuk menggali kekayaan alam suatu daerah dengan mudah. (http://:indonesia-people-of-wera-resistiron-sand-mining-corporations \& catid diunduh 2 Mei 2011).

Daerah Istimewa Yogyakarta memiliki potensi luar biasa sumber daya alam bahan baku baja yang berupa pasir besi, khususnya di pantai selatan Kabupaten Kulon Progo. Jika potensi ini dapat dimanfaatkan dan dikelola dengan baik akan menghasilkan sekitar 1 juta ton pig iron, berarti paling tidak akan memenuhi sekitar $50 \%$ bahan baku baja nasional yang saat ini masih diimpor. Saat ini bahan baku baja yang berupa biji besi terolah 100\% masih impor dari Amerika Selatan, dengan ongkos angkut sekitar $\$ 60$ per ton. Jika Indonesia mampu memproduksi sendiri bahan baku baja, dari ongkos angkut sendiri bisa menghemat sekitar $\$ 50.000 .000$ per tahun (Bambang Yunianto, 2008: 12)

Sebelum ada rencana penambangan pasir besi, lahan pantai selatan Kulon Progo telah menjadi lahan pertanian yang subur. Warga mulai mengolah lahan pantai dibantu tim peneliti dari Fakultas Pertanian Universitas Gadjah Mada yang memperkenalkan teknik bertani di lahan pasir. Saat ini lahan pasir yang awalnya kering telah menjadi hamparan tanaman. Lahan tersebut telah meningkatkan kesejahteraan belasan ribu petani di sepanjang pantai Kulon Progo. Kalangan akademis dari Universitas Gadjah Mada juga menjadikan pertanian gumuk pasir sebagai laboratorium hidup bagi penelitian mereka.

Lahan pantai selatan Kulon Progo sepanjang 22 km dalam sejarah diklaim sebagai 
tanah Paku Alam Ground (PAG). Hal ini dikarenakan Undang-undang Nomor 3 Tahun 1950 tentang Pembentukan Daerah IstimewaYogyakarta masih tetap mengakui berlakunya rijksblad-rijksblad maupun peraturan-peraturan daerah, selain itu Daerah Istimewa Yogyakarta juga belum memberlakukan UU No. 5 Tahun 1960 tentang hak dan wewenang atas bumi dan air, Swapraja dan bekas Swapraja yang beralih pada negara sejak berlakunya Undang-Undang Pokok Agraria (UUPA). Permasalahan status hukum hak atas tanah Paku Alam Ground (PAG) sampai saat ini masih menjadi perdebatan karena secara yuridis keistimewaan Paku Alam Ground dibidang pertanahan belum mendapatkan legitimasi dalam peraturan perundang-undangan setelah dikeluarkan $\begin{array}{llllll}\text { Keppres } & \text { RI } & \text { Nomor } & 33 & \text { Tahun } & 1984\end{array}$ (http://www.ibnurochimconnection.com/2009/2/kedudukan-hukum-tanah-adat-di daerah.html,diunduh 17 januari 2011)

Di sepanjang tanah pesisir selatan Kulon Progo, saat ini sedang berjalan rencana pendirian tambang pasir besi. Rencana pertambangan pasir besi di Kabupaten Kulon Progo muncul dari perusahaan keluarga Kasultanan/Paku Alaman (Akta Notaris PT Jogja Magasa Mining No.40. Buntario Tigris Darmawa NG, SH, SE) kepada pemerintah daerah. Rencana pertambangan pasir besi juga mendapat dukungan dari Sri Sultan Hamangku Buwono X seperti yang dikutip pada TubasMedia.com

Sri Sultan juga merasakan keyakinannya, Pasir besi di Kabupaten Kulon Progo itu merupakan emas hitam bagi DIY. Apalagi pasir besi di Kulon Progo memiliki perbedaan dengan pasir besi di daerah lainnya. Karena kandungan Vanadiumnya, sejauh ini diketahui hanya terdapat pada pasir besi di Kulon Progo dan Meksiko.

Dikatakan Sri Sultan, keberadaan dan potensi pasir besi di Kulonprogo itu dapat dipastikan akan mampu mendukung pertumbuhan perekonomian DIY. Karena nantinya akan didukung pula dengan adanya pembangunan inlandport berupa bandara dan pelabuhan. Dan, keberadaan inlandport itu nantinya akan menimbulkan multiplier effect bagi DIY. (http://www.tubasmedia.com/berita/pasir-besi-kulonprogo-emas-hitam-diy/,diunduh tanggal 16 Mei 2011)

Apabila pengolahan pasir besi di pesisir selatan dan pembangunan bandara internasional sebagai pengganti bandara Adisutjipto dapat terealisasi, maka kesejahteraan masyarakat setempat dapat ditingkatkan, sehingga Kulon Progo akan menjadi kabupaten terkaya di Provinsi Daerah Istimewa Yogyakarta

Rencana penambangan pasir besi akan dilakukan oleh PT. Jogja Magasa Mining Yogyakarta dan Indo Mines Limited Australia di sepanjang pesisir pantai selatan Kulon Progo dengan luas kurang lebih 4.000 ha, panjang sekitar $22 \mathrm{Km}$ dan lebar sekitar 1,8 Km dari bibir pantai. (PT. JMM, 2006b)

Awalnya rencana penambangan pasir besi tersebut cenderung menimbulkan penolakan dari masyarakat setempat. Penolakan tersebut didasari atas kekhawatiran sebagian masyarakat setempat bahwa jika pembangunan pabrik biji besi tersebut terlaksana maka akan membawa dampak serius bagi kerusakan ekosistem dan lingkungan setempat. Terlebih lagi, lahan persawahan yang menjadi mata pencaharian sebagian besar masyarakat tersebut akan mengalami penurunan kualitas kesuburan tanahnya. Ini berarti masyarakat petani di wilayah yang terkena proyek pembangunan tersebut akan 
Dampak Rencana Penambangan Pasir Besi terhadap Kondisi Sosial Petani Lahan Pantai di Desa Banaran Kecamatan Galur Kabupaten Kulon Progo

kehilangan sumber mata pencaharian.

Namun suara petani lahan pasir di Kulon Progo yang sebelumnya cenderung menolak proyek penambangan pasir besi mulai pecah. Petani di Desa Banaran Galur, kini ada yang mendukung PT. Jogja Magasa Mining melanjutkan penambangan di sana setelah dijanjikan akan mendapat izin menggunakan lahan pasca penambangan. Menurut Ketua Sekretariat Bersama Petani Penggarap Tanah Paku Alam, bapak Abdullah Iman, PT. Jogja Magasa Mining (JMM) menjanjikan akan membantu petani Banaran mengurus izin penggunaan lahan pasir (magersari) dari Kraton Pakualaman pasca penambangan. Selain itu, petani juga diuntungkan oleh proyek itu karena PT. JMM akan memberi ganti rugi atas komoditas tanaman pertanian yang tengah tumbuh di lahan pasir itu saat penambangan JMM berlangsung. Pendapat sebaliknya dikemukakan Ketua Paguyuban Petani Lahan Pantai (PPLP) Kulon Progo Supriyadi. Ia menegaskan, PPLP akan tetap menolak proyek senilai lebih dari 600 juta dollar AS itu karena proyek tersebut merampas lahan petani (Kompas.com diunduh 17 Januari 2011)

Dampak sosial telah dirasakan masyarakat pesisir meskipun pertambangan pasir besi baru dalam tahap persiapan. Suhu politik di pesisir Kulon Progo memicu konflik horizontal di antara warga yang pro dan kontra. Contohnya pada tanggal 9 April 2011 terjadi aksi penyaderaan terhadap tujuh buruh bangunan dari Desa Banaran di pilot project penambangan pasir besi milik PT. JMI.

\section{Metode Penelitian}

Penelitian ini merupakan penelitian deskriptif kuantitatif yaitu penelitian yang bertujuan menggambarkan keadaan atau fenomena yang ada. Penelitian ini lebih mengarah pada pengungkapan fakta-fakta yang ada, walaupun kadang-kadang diberi interpretasi deskriptif berfungsi dalam pengadaan suatu spesifikasi mengenai gejalagejala fisik maupun sosial yang dipersoalkan (Moh. Pabundu Tika, 2005: 4).

Penelitian ini dilaksanakan pada bulan Oktober sampai November 2011, di Desa Banaran Kecamatan Galur Kabupaten Kulon Progo. Populasi adalah keseluruhan subjek penelitian (Suharsimi Arikunto, 1993: 102). Sesuai dengan tujuan penelitian maka populasi dalam penelitian ini adalah seluruh kepala rumah tangga petani penggarap lahan pantai di Desa Banaran dengan jumlah 322 kepala rumah tangga petani. Sampel adalah sebagian dari objek atau individu yang mewakili suatu populasi (Moh. Pabundu Tika, 2005: 24). Menurut Suharsimi Arikunto (2006: 131) sampel adalah sebagian atau wakil populasi yang diteliti. Pengambilan sampel ditentukan dengan teknik simple random sampling. Metode ini digunakan untuk mendapatkan sampel yang langsung dilakukan pada unit sampling sebagai unsur populasi yang terkecil memperoleh peluang yang sama untuk menjadi sampel atau untuk mewakili populasi (Nurul Zuriah, 2007: 123). Jumlah sampel dalam penelitian ini adalah 33 responden. Variabel dalam penelitian ini adalah:

a. Sikap penduduk Desa Banaran terhadap rencana penambangan pasir besi

b. Dampak sosial rencana penambangan pasir besi Definisi Operasional Variabel Penelitian:

a. Sikap penduduk Desa Banaran yakni tanggapan penduduk 
Desa Banaran baik yang menyetujui maupun yang menolak rencana penambangan pasir besi

b. Dampak sosial rencana penambangan pasir besi adalah akibat yang baik maupun buruk yang dapat dilihat secara langsung dalam interaksi sosial yang disebabkan oleh rencana penambangan pasir besi. Dampak sosial tersebut meliputi:

1) Dampak berdirinya pilot project terhadap kenyamanan tempat tinggal petani lahan pantai

2) Frekuensi dan jenis kegiatan sosial petani lahan pantai setelah adanya rencana penambangan pasir besi.

3) Kerukunan antar warga setelah adanya rencana penambangan pasir besi.

4) Dampak pilot project terhadap aktifitas keseharian petani lahan pantai.

Teknik pengambilan data yang akan digunakan dalam penelitian ini adalah:

a. Observasi

Metode ini digunakan untuk mengetahui kondisi sosial di Desa Banaran terkait dengan adanya rencana penambangan pasir besi, sehingga ketika peneliti melakukan penelitian tidak salah dalam mengambil tindakan terkait dengan konflik sosial yang terjadi di sana,

b. Dokumentasi

Dokumentasi juga dilakukan dengan mengambil foto atau gambar. Metode ini digunakan untuk mengumpulkan teori-teori yang mendukung dalam penelitian.

c. Wawancara

Metode ini digunakan untuk mencari data tentang sikap petani lahan pantai terhadap rencana penambangan pasir besi serta dampak sosial yang terjadi akibat rencana penambangan pasir besi. Alat yang digunakan adalah pedoman wawancara.

Penelitian ini menggunakan analisis deskriptif kuantitatif yaitu dengan menggunakan alat sederhana berupa rata-rata, tabulasi silang dan frekuensi distribusi. Data dalam penelitian ini ditampilkan melalui tabel frekuensi yang disajikan dalam angka persentase. Setelah data disajikan dalam bentuk table-tabel frekuensi kemudian dianalisis berdasarkan teori yang ada.

\section{Hasil Penelitian dan Pembahasan}

Berdasarkan hasil penelitian, maka dapat diperoleh informasi tentang sikap petani lahan pantai terhadap rencana penambangan pasir besi serta dampak sosial yang terjadi akibat rencana penambangan pasir besi di Desa Banaran sebagai berikut:

1. Sikap Petani Terhadap Rencana Penambangan Pasir Besi

a. Sikap Petani Terhadap Rencana Penambangan Pasir Besi

Rencana penambangan pasir besi di sepanjang pesisir selatan Kulon Progo menimbulkan pro dan kontra. Lebar area pertambangan yakni 1,8 km dari bibir pantai tentu akan mengenai lahan pertanian dan rumah penduduk. Berikut disajikan respon penduduk terhadap rencana penambangan pasir besi. 
Tabel 1. Sikap Petani Terhadap Rencana Penambangan Pasir Besi

\begin{tabular}{|c|c|c|c|}
\hline No & Respon & Frekuensi & Persentase (\%) \\
\hline 1 & Setuju & 22 & 66,67 \\
\hline 2 & Tidak Setuju & 8 & 24,24 \\
\hline 3 & Terserah Pemerintah & 3 & 9,09 \\
\hline \multicolumn{2}{|c|}{ Jumlah } & 33 & 100 \\
\hline
\end{tabular}

Sumber : Data Primer, November 2011

Berdasarkan tabel 1 dapat diketahui bahwa sebagian besar responden setuju secara terang-terangan sebesar 66,67 persen, dan terserah pemerintah sekitar 9,09 persen. Pemerintah juga sangat mendukung adanya rencana penambangan pasir besi, hal ini karena dengan adanya penambangan pasir besi Pendapatan Asli Daerah (PAD).

b. Alasan Setuju atau Tidak Setuju Petani Terhadap Rencana Penambangan Pasir Besi

Berikut ini disajikan tabel alasan responden setuju maupun tidak setuju terhadap rencana penambangan pasir besi.

Tabel 2. Alasan Setuju atau Tidak Setuju Terhadap Rencana Penambangan

Pasir Besi

\begin{tabular}{|c|c|c|c|}
\hline Sikap & Alasan Setuju atau Tidak Setuju & Frekuensi & Persentase (\%) \\
\hline \multirow{4}{*}{ Setuju } & Partisipasi dalam pembanqunan & 3 & 9,09 \\
\hline & Program pemerintah & 2 & 6,06 \\
\hline & Menciptakan lapangan kerja baru & 11 & 33,33 \\
\hline & $\begin{array}{l}\text { Mendapat ganti rugi selama tanah } \\
\text { Disewa }\end{array}$ & 9 & 27,27 \\
\hline \multirow{2}{*}{$\begin{array}{l}\text { Tidak } \\
\text { setuju }\end{array}$} & $\begin{array}{l}\text { Menimbulkan dampak negatif pada } \\
\text { Lingkungan }\end{array}$ & 2 & 6,06 \\
\hline & Kehilangan mata pencaharian utama & 6 & 18,18 \\
\hline & Jumlah & 33 & 100 \\
\hline
\end{tabular}

Sumber : Data Primer, November 2011

Responden sebanyak 75,76 persen yang setuju terhadap rencana penambangan pasir besi, 9,09 persen setuju dengan alasan sebagai partisipasi dalam pembangunan, sedangkan 6,06 persen dari responden setuju karena penambangan pasir besi merupakan program pemerintah. Alasan terbanyak responden setuju rencana penambangan pasir besi, yakni 33,33 persen karena adanya pertambangan pasir besi menciptakan lapangan kerja baru bagi penduduk. sembilan responden atau 27,27 persen setuju karena PT JMI akan memberi ganti rugi terhadap tanah dan tanaman yang digunakan untuk pertambangan selama dua tahun yang besarnya mengacu pada perhitungan besar pendapatan petani yang telah hilang selama dua tahun karena tidak menggarap lahan itu. Selain itu PT JMI akan membantu dalam ijin penggunaan lahan pasir pasca penambangan.

Sebanyak 6,06 persen yang tidak setuju dengan adanya rencana penambangan pasir besi dengan alasan adanya penambangan pasir besi akan menimbulkan instrusi air laut karena gumuk pasirnya diambil. Selain itu 
sebanyak 6 responden atau 18,18 persen khawatir tanah mereka akan diambil untuk dijadikan areal pertambangan, jika tanah mereka diambil tentu saja mereka akan kehilangan mata pencaharian utama mereka.

c. Dampak Rencana Penambangan Pasir Besi Terhadap Kondisi Sosial Rumah Tangga

1) Dampak Pilot Project Terhadap Kenyamanan Tempat Tinggal

Berikut ini disajikan tabel dampak berdirinya pilot project terhadap kenyamanan tempat tinggal petani.

Tabel 4. Dampak Pilot Project Terhadap Kenyamanan Tempat Tinggal

\begin{tabular}{|c|c|c|c|}
\hline No & Pandangan Responden & Frekuensi & Persentase (\%) \\
\hline 1 & Tidak mengganggu & 25 & 75,76 \\
\hline 2 & Debit air sumur menyusut & 8 & 24,24 \\
\hline \multicolumn{2}{|c|}{ Jumlah } & 33 & 100 \\
\hline
\end{tabular}

Sumber : Data Primer, November 2011

Berdasarkan tabel 4, dapat dijelaskan bahwa sebesar 75,76 persen responden memandang adanya pilot project tidak menganggu aktivitas mereka, sedangkan 24,24 persen berpendapat bahwa dengan adanya pilot project debit air sumur menjadi menyusut.

2)

mpak Rencana Penambangan Pasir Besi Terhadap Frekuensi Kegiatan Sosial

Pro dan kontra terhadap rencana penambangan pasir besi turut mempengaruhi frekuensi kegiatan sosial yang diadakan oleh warga masyarakat setempat.

Tabel 5. Frekuensi Kegiatan Sosial Sesudah Ada Rencana Penambangan Pasir Besi

\begin{tabular}{|c|c|c|c|}
\hline No & Frekuensi Kegiatan Sosial & Frekuensi & Persentase (\%) \\
\hline 1 & Sama Saja & 16 & 48,49 \\
\hline 2 & Semakin Berkurang & 10 & 30,30 \\
\hline 3 & Semakin Baik & 7 & 21,21 \\
\hline \multicolumn{2}{|c|}{} \\
\hline
\end{tabular}

Sumber : Data Primer, November 2011

Berdasarkan table 5 dapat djelaskan bahwa dari 48,49 persen atau 16 responden menyatakan bahwa keberadaan kegiatan sosial di daerah mereka sama saja. Ini bisa disebabkan karena masyarakat daerah mereka sepakat memilih pro pasir besi saja atau anti pasir besi saja, sehingga adanya pro dan kontra ini tidak berpengaruh terhadap frekuensi kegiatan sosial mereka. Sedangkan 30,30 persen atau 10 responden menyatakan bahwa kualitas kegiatan sosial mereka semakin berkurang. Alasan responden memilih semakin berkurang karena sering terjadi keributan antar warga. Ada juga warga yang takut mengikutikegiatan kemasyarakatan karena mereka takut dicap sebagai yang berseberangan dengan masyarakat sekitar. Pada tabel diatas 21,21 persen menyatakan bahwa frekuensi kegiatan sosial semakin baik, alasannya karena kesadaran hidup masyarakat dalam bergotong royong masih tinggi, ditambah lagi adanya pro kontra yang bisa merusuk kerukunan antar warga, jika masyarakat tidak 
meningkatkan frekuensi dan kualitas kegiatan sosial maka kesadaran hidup bermasyarakat lama-lama akan pudar.

3) Dampak Rencana Penambangan Pasir Besi Terhadap Kerukunan Antar Warga

Rencana penambangan pasir besi menimbulkan sengketa kepentingan hak atas dan konflik sosial penolakan pendirian tambang pasir besi. Dampak sosial yang paling dirasakan oleh masyarakat yaitu kerukunan antar warga akibat pro dan kontra terhadap pendirian tambang pasir besi.

Tabel 6. Dampak Rencana Penambangan Pasir Besi Terhadap Kerukuna Antar Warga

\begin{tabular}{|c|c|c|c|}
\hline No & Kerukunan Antar Warga & Frekuensi & Persentase (\%) \\
\hline 1 & Sama saja & 5 & 15,15 \\
\hline 2 & Semakin berkurang & 8 & 24,24 \\
\hline 3 & Semakin baik & 20 & 60,61 \\
\hline \multicolumn{2}{|r|}{ Jumlah } & 33 & 100 \\
\hline
\end{tabular}

Sumber : Data Primer, November 2011

Berdasarkan tabel 6 dapat dijelaskan bahwa 15,15 persen responden menyatakan bahwa rencana penambangan pasir besi tidak mempengaruhi kerukunan antar warga di Desa Banaran, sedangkan 24,24 responden menyatakan bahwa adanya rencana penambangan pasir membuat kerukunan antar warga berkurang. Umumnya responden beranggapan bahwa adanya pro dan kontra terhadap rencana penambangan pasir besi membuat kerukunan antar warga semakin berkurang. Sebanyak 60,61 persen responden menyatakan bahwa adanya pro dan kontra terhadap rencana penambangan pasir besi sebaliknya justru membuat kerukunan antar warga semakin baik. Responden tidak menginginkan adanya rencana penambangan pasir besi memicu profokasi dari pihak-pihak tertentu, sehingga hubungan silaturahmi antar warga ditingkatkan.

\section{Kesimpulan}

Berdasarkan penelitian dan pembahasan diatas, maka dapat diambil kesimpulan sebagai berikut :

1. Sebanyak 75,76 persen penduduk Desa Banaran menyetujui adanya penambangan pasir besi di Desa Banaran karena dapat menciptakan lapangan pekerjaan baru sehingga tingkat kesejahteraan mereka akan meningkat. Penduduk yang tidak setuju

2. 24,24 persen karena merasa takut jika rencana penambangan pasir besi terlaksana akan menggusur lahan pertanian mereka, sehingga penduduk akan kehilangan mata pencaharian utama .

3. Dampak sosial rencana penambangan pasir besi terhadap kondisi sosial masyarakat petani antara antara lain :

a. Berdirinya pilot project di Desa Banaran menurut 75,76 persen responden tidak berpengaruh terhadap kenyamanan tempat tinggal mereka, sedangkan 24,24 persen responden mengaku adanya responden membuat debit air sumur mereka berkurang.

b. Rencana penambangan pasir besi tidak mempengaruhi 
frekuensi kegiatan sosial masyarakat Desa Banaran. Bahkan menurut 21,21 persen responden mengaku bahwa frekuensi kegiatan sosial semakin baik karena adanya rencana pasir besi dapat merusak kerukunan hidup warga, sehingga frekuensi kegiatan social ditingkatkan. Responden yang mengaku frekuensi kegiatan social berkurang umumnya beralasan bahwa warga takut mengikuti kegiatan sosial yang diadakan karena takut dicap sebagai yang berseberangan dengan masyarakat sekitar.

C.

Keberadaan rencana penambangan pasir besi tidak mengurangi kerukunan antar warga di Desa Banaran, justru semakin baik. Artinya konflik horizontal yang dikhawatirkan tidak terjadi.

\section{Saran}

Dari hasil penelitian dan kesimpulan diatas, dapat dikemukakan saran sebagai berikut :

1. Bagi Pemerintah

Sudah merupakan kebijakan pemerintah sebelum penambangan pasir besi dimulai, terlebih dahulu meminta PT JMI untuk melakukan kajian dengan menyusun dokumen Analisis Mengenai Dampak Lingkungan (AMDAL). Penyusunan AMDAL harus jelas dan ada partisipasi dari warga pesisir selatan. Dengan adanya AMDAL inilah yang akan menjadi pertimbangan, apakah lahan pesisir selatan layak ditambang atau tidak. Selain itu sosialisasi pada warga pesisir perlu ditingkatkan oleh pemerintah dengan berbagai pendekatan, karena kekayaan pasir besi di Kulon Progo bukanlah barang yang harus diterlantarkan.

Pemerintah bisa memanfaatkan pilot project yang sudah ada sebagai media sosialisasi kepada warga pesisir, karena dengan melihat pilot project warga akan mengetahui bagaimana proses kegiatan penambangan berlangsung.

2. Bagi Petani Lahan Pantai

Warga pesisir hendaknya untuk memanfaatkan forum sosialisasi yang dilakukan oleh pemerintah maupun PT JMI sebagai media menyampaikan tanggapan, saran dan harapan serta keinginan warga pesisir selatan Kulonprogo terhadap rencana penambangan pasir besi.

Rencana penambangan pasir besi di pesisir Kulon Progo diharapkan tidak menimbulkan konflik horizontal dikalangan masyarakat yang setuju dengan yang tidak. Pada dasarnya tujuan dari penambangan pasir besi di pesisir selatan Kulon Progo adalah untuk mensejahterakan warga pesisir. Sangat disayangkan kekayaan pasir besi di sepanjang pesisir selatan Kulon Progo dibiakan begitu saja.

Keberadaan pilot project di Desa Banaran hendaknya dimanfaatkan oleh warga guna melihat proses penambangan secara langsung, karena berdasarkan uji coba di pilot project, lahan yang sudah diambil kandungan logamnya, setelah direklame tingkat kesuburannya lahan justru bertambah.

\section{Daftar Pustaka}

Badan Pusat Statistik Kabupaten Kulon Progo. 2009. Kabupaten Kulon Progo Dalam Angka.

Dinas Pariwisata Pemerintah Provinsi Dearah Istimewa Yogyakarta dan Jurusan 
Dampak Rencana Penambangan Pasir Besi terhadap Kondisi Sosial Petani Lahan Pantai di Desa Banaran Kecamatan Galur Kabupaten Kulon Progo

Tehnik Arsitektur Fakultas Tehnik Universitas Gadjah Mada. 1999. Kajian Ulang Ripow Pantai Trisik Kabupaten Kulon Progo. Yogyakarta.

Ida Bagus Mantra. 1985. Pengantar Studi Demografi. Yogyakarta: Nur Cahaya. Nasution S.2006. Metode Research. Jakarta: Bumi Aksara.

Nurul Zuriah. 2007. Metode penelitian Sosial dan Pendidikan. Jakarta :Bumi Aksara. Pabundu Tika, Muh. 2005. Metode Penelitian Geografi. Jakarta: Bumi Aksara.

Sugiyono. 2009. Metode Penelitian Pendidikan Pendekatan Kuantitatif, Kualitatif, dan $R \& D$. Bandung:Alfabeta.

Suharsimi Arikunto. 1997. Prosedur Penelitian Suatu Pendekatan Praktek. Jakarta : Rineka Cipta.

Yunianto Bambang.2009. Kajian Permasalahan Lingkungan Dan Sosial Ekonomi Rencana Penambangan Dan Pengelolaan Pasir Besi di Pantai Selatan Kulon Progo Yogyakarta. Bandung :Puslitbang Teknologi Mineral dan Batubara.

http://www.ibnurochimconnection.com/2009/2/kedudukan-hukum-tanah-adat-di daerah.html, 27 April 2011, Jam 19.18 WIB.

http://indigenouspeoplesissues.com/index.php?option=com_content\&view=article\&id $=1$ 0023:indonesia-people-of-wera-resist-iron-sand-mining-corporations\&catid $=62$ :southeast-asia-indigenous-peoples\&Itemid=84 diunduh 2 Mei 2011.

http://www.kulonprogo.go.id/main.php?what=hmtl/profil/sejarah,17 Januari 2011，Jam 15.45 WIB.

http://www.tubasmedia.com/berita/pasir-besi-kulonprogo-emas-hitam-diy/-diunduh tanggal 16 Mei 2011. 